\title{
Health Risk Assesment of Cadmium (Cd) and Chromium (Cr) Exposure to Society in Coastal Areas of Jeneponto Regency
}

\author{
Anwar Daud*, Muhammad Rifaldi Anwar, Annisa Utami Rauf, Ervina Septami AR, Rahmat \\ Hidayat, Nano Hajra EL
}

Department of Environmental Health, Faculty of Public Health, Hasanuddin University Indonesia

\section{*Corresponding Author}

Anwar Daud

\section{Article History}

Received: 29.07.2020

Accepted: 05.08.2020

Published: 07.08.2020

\begin{abstract}
Heavy metal pollution is a serious challenge because of its bioaccumulation capabilities in the food chain. Cadmium (Cd) and chromium (Cr) are unsupported which are not needed by all residents, this requires a lot of money. human. This study uses ARKL studio which is used to determine the level of health risks from the consumption of shellfish containing heavy metals $\mathrm{Cd}$ and $\mathrm{Cr}$ in the Jeneponto Coastal community. Samples were taken in two villages namely Mallasoro Village, Bangkala District, and Bonto Ujung Village, Tarowang Sub-District, Jeneponto Regency, South Sulawesi. Sampling was done by purposive sampling. Air samples are taken, sediments and shellfish are taken directly from the area. Analysis of heavy metal concentrations $(\mathrm{Cd}$ and $\mathrm{Cr}$ ) in air, sediments and shells was carried out with Atomic Absorption Spectrophotometer (AAS). Average concentrations of $\mathrm{Cd}$ and $\mathrm{Cr}$ in the sample as follows $\mathrm{Cd}$ Water (0.048mg / L); Cr Water (0.374 mg / L); Sediment CD (2,054 mg / kg); Cr Sediment (12.69 mg / kg); CD shells $(1,236 \mathrm{mg} / \mathrm{kg})$; Cr shells $(2,861 \mathrm{mg} / \mathrm{kg})$. The results showed the intake of Cr; $2,8611 \mathrm{mg} / \mathrm{kg}$ and Cd; $0.007 \mathrm{mg} / \mathrm{kg} /$ day, Analysis of the level of risk to get RQ> 1. (Risk Qotient) with an average CD; 13.509 and $\mathrm{Cr} ; 5.212$ which means "high risk". The high health risk obtained from the accumulation of $\mathrm{Cd}$ and $\mathrm{Cr}$ indicates that shellfish are no longer safe for consumption. The recommendation obtained from this study is about the consumption of shellfish by the people around the Jeneponto Coastal Coast. High levels of heavy metals in sediment media that show shells have accumulated to the bottom of the coastline so that environmental quality is needed. Health risk assessments that have been carried out indicate that marine and shellfish products on the coast have exceeded safe limits.
\end{abstract}

Keywords: Cadmium, Chromium, Risk Analysis, Health.

\section{INTRODUCTION}

The element Cadmium (Cd) was discovered in 1817 by F. Strohmeier, a German chemist. Cadmium is a simple element, and is located far below the surface of the earth. It is a very poisonous element, and its commercial use is prohibited until the end of the 19th century. Its texture is like soft metal, and bluish white. Its chemical properties are similar to two stable metals, mercury and zinc, which are in group 12 on the periodic table, with a melting point of $321^{\circ}$ $\mathrm{C}$ and boiling point of $767^{\circ} \mathrm{C}$ [1]. Cadmium is not needed by the body, and is toxic, and has an unhealthy effect on the human body, especially on bones [5]. Cadmium can accumulate in the kidneys and liver, and may be a source of contamination in the future as an inhaled carcinogen [2].

Cadmium $(\mathrm{Cd})$ is a poisonous element that is not needed by all living organisms. This poses many environmental threats which can ultimately cause disruption to plants and diseases in humans. It can accumulate in various organs of the human body because of its persistent nature [4]. Heavy metal chromium $(\mathrm{Cr})$ is a heavy metal with an atomic weight of $51.996 \mathrm{~g} / \mathrm{mol}$, gray, resistant to oxidation even at high temperatures, shiny, hard, has a melting point of $1,857^{\circ} \mathrm{C}$ and boiling point of $2,672^{\circ} \mathrm{C}$, is paramagnetic, forming compounds - colored compounds, have oxidation numbers that are $+2,+3,+6$, and are stable at +3 . Oxidation numbers +4 and +5 are rarely found in this metal. Chromium compounds in the +6 oxidation number are strong oxidants. Chromium metal is a chemical that is persistent,

Copyright @ 2020: This is an open-access article distributed under the terms of the Creative Commons Attribution license which permits unrestricted use, distribution, and reproduction in any medium for non commercial use (NonCommercial, or CC-BY-NC) provided the original author and source are credited. 
bioaccumulative, and toxic (PBT) which is high and unable to decompose, and finally accumulated in the human body through the food chain [13].

The concentration of cadmium on earth is around 0.1 to $0.5 \mathrm{ppm}$, but sedimentary rocks can accumulate higher levels. Phosphorus (nonde-trital sedimentary rocks) and marine phosphate have been observed with a cadmium concentration of $500 \mathrm{ppm}$. Erosion and weathering of rock material cause large amounts of cadmium to be transported through rivers (around 15,000 $\mathrm{mt}$ (metric tons) of cadmium) to the world's oceans annually. Volcanic eruptions and forest fires are also a major source of naturally occurring cadmium emissions, and around 820 metric tons of cadmium released annually into the atmosphere due to volcanic activity, and up to 70 metric tons of cadmium annual emissions caused by forest fires [6]. Cadmium in the environment is also toxic to microorganisms, plants, and animals, because cadmium is a chemical element that is simple and persistent in nature, so it is not easily broken down into compounds that are less toxic in the environment [7].

Chromium can naturally be found in rocks, plants, animals, soil and gas, as well as volcanic dust. Chromium (III) naturally occurs in nature, while $\mathrm{Cr}(0)$ and $\mathrm{Cr}$ (IV) generally come from industrial processes. Pure chromium metal has never been found, but is usually already in the form of solid compounds or minerals with other elements. Some minerals, chromium are found in the form of chromite (FeOCr2O3). The inclusion of $\mathrm{Cr}$ metal into the general environmental strata and is used the most in industrial activities, household activities, and from combustion and mobility of fuels. The entry of $\mathrm{Cr}$ naturally can be caused by several physical factors, such as erosion that occurs in mineral stones. Besides that it can also be caused by dust and Cr particles in the air will be carried down by rain water [13].

Lower Cd levels over a long period of time can cause a buildup of metal in the kidneys, with possible damage. Chronic exposure to low Cd levels can also cause bones to become brittle and break easily. IARC classifies Cd and its compounds as carcinogenic to humans. This evaluation is based on carcinogenic effects in the lungs after inhalation, but tumors have also been observed in other organs (prostate and kidney). The use of Cd in cosmetic products is due to its color properties and has been used as a color pigment in many industries [10]. Cd sulfide is used for yellow, while, by adding an increasing amount of selenium, colors ranging from orange to practical black (Cd selenide color) can be produced. Yellow cadmium is sometimes mixed with viridian ( $\mathrm{Cr}$ (III) oxide) to give a light green mixture called green cadmium. Although the presence of $\mathrm{Cd}$ in cosmetic samples can be traced to the count [11] and absorption through the skin is not a significant entry point for $\mathrm{Cd}$, slow release of $\mathrm{Cd}$ can cause harmful effects to the human body.

The threshold for acute cadmium toxicity appears to be a total consumption of $3-15 \mathrm{mg}$. Severe toxic symptoms are reported by swallowing 10-326 mg. Fatal consumption of $\mathrm{Cd}$, resulting in shock and acute renal failure, occurs with consumption in excess of $350 \mathrm{mg}$ [9] A lack of chromium in growth causes impaired metabolism of glucose, lipids, and proteins [12] Chromium was detected in all samples studied and concentrations fluctuated between 3.72 and a dry weight of $18.58 \mathrm{lg} / \mathrm{g}$. The highest $\mathrm{Cr}$ concentration was detected at D. venustus collected from the Port-Said station. All bivalve samples collected showed $\mathrm{Cr}$ concentrations below or within the FDA range [8].

\section{MeTHODS}

\section{Research design}

The time of this research was 6 months, from April to September 2017. The location of the study was determined based on cases of poisoning of people who consume shellfish, namely in Mallasoro Village, Bangkala District, and Bonto Ujung Village, Tarowang District, Jeneponto Regency, South Sulawesi. This study used an Observational design with the Environmental Health Risk Analysis (ARKL) approach to identify the pattern of heavy metal distribution and public health risk analysis on the coast of Jeneponto District. This research was conducted in Bangkala District and Tarowang District, Jeneponto Regency, South Sulawesi.

\section{Population and Sample}

The research sample was taken by purposive sampling. The criteria for the sample of the population taken are residents aged 15 years and over, consuming shellfish from sea catches at least once a month and living for a minimum of 1 year in that place. Water, Sediment and Shellfish samples were taken as many as 18 points with details in Bangkala sub-district as many as 10 points and in Tarowang sub-district as many as 8 sampling points while the population sample plan taken in phase I in this study was as many as 100 respondents with details of 50 samples per district and in phase II as many as 40 respondents with details of 20 samples per district that had experienced poisoning at August-October 2016.

\section{Water and Sediment Sampling}

Sampling was carried out at two observation stations. Determination of the sampling point is done using GPS. Water samples are taken in the water column using vandorn water samples. Water samples that have been taken are then divided into two bottles. The first bottle is a $250 \mathrm{ml}$ polyetilen bottle for turbidity analysis while the second bottle, a 500 
$\mathrm{ml}$ polyetilen bottle, for heavy metal analysis where the bottle has been added with preservative HNO3, then the bottle is put into the coolbox. Sediment sampling is done directly by using $1 \mathrm{~kg}$ of hand. The sediment that has been obtained is put into a sample collection place (black plastic bag) and stored in a coolbox, then taken to the laboratory for analysis.

\section{Sampling of blood shells}

Sampling of blood clams was carried out at two predetermined observation stations, using the 5 x 5 meter transect method and blood clams were taken using hand swipe techniques at 1 meter intervals. The number of shellfish taken is based on the catch when sampling blood shells. Furthermore, the sample blood shells measured the length of the shell, then grouped into two, namely small (shell length $\leq 3 \mathrm{~cm}$ ) and large (shell length $>3 \mathrm{~cm}$ ).

Biota sampling was done to see the heavy metal content of $\mathrm{Pb}$ and $\mathrm{Cr}$. Examples of biota needed for this are 10 grams of each clam meat which has been dissected from small and large shells. To obtain this amount of meat, at least 5 to 10 blood clams are needed and dried for 2 days, then finely ground until ready for analysis.

\section{Measurement of Heavy Metal Content in Shells, Water and Sediments}

Measurement of heavy metal content of $\mathrm{Cd}$ and $\mathrm{Cr}$ in the sample is done in the laboratory. The analysis process was carried out using the AAS method using furnaces with argon gas and Cd lamps, and $\mathrm{Cr}$, according to the type of metal to be analyzed.

\section{Data analysis}

\section{Bioconcentration Factor $(\mathrm{BCF})$}

The ability of aquatic biota to accumulate heavy metals can be seen from the concentration factor index which compares the concentration of heavy metals in blood clams with the concentration of heavy metals in water.

Information:

$$
B C F=\frac{[L] \text { Shellfish }}{[L] \text { Water }}
$$

[L] shellfish are heavy metals in shells (ppm)

[L] Water is the concentration of heavy metals in water (ppm)

\section{Calculation of intake (intake) and risk level $(R Q)$}

The intake rate calculation is used to calculate $\mathrm{Cd}$ and $\mathrm{Cr}$ metal intake in each sample consumed by the community. the formula is as follows:

$$
I=\frac{C \times R \times F_{e} \times D_{t}}{W_{b} \times t_{\text {avg }}} \text { Intake by Ingesti }
$$

\section{Information}

I: intake (the amount of $\mathrm{Cd}$ and $\mathrm{Cr}$ that enters the human body / body weight / day population exposed to) $\mathrm{mg} / \mathrm{kg} / \mathrm{day}$,

$\mathrm{C}: \mathrm{Cd}$ and $\mathrm{Cr}$ concentrations in shellfish

Fe: frequency of exposure (day / year)

$\mathrm{Wb}$ : respondent's weight

$\mathrm{R}$ : intake rate (grams / day)

Dt: duration of exposure (years), 30 years for exposure to chemicals with non-effects carcinogenic and 70 years for exposure to chemicals with effects carcinogenic tavg: average time period (Dt x 365 days / year for carcinogenic and non-carcinogenic effects) carcinogenic).

Whereas to determine the level of risk (RQ) can be determined using the following formula:

\section{Information}

$$
R Q=\frac{I}{R f D}
$$

I: intake ( $\mathrm{mg} / \mathrm{kg} /$ day)

RFD: Dose reference heavy metal that has been determined

If $\mathrm{RQ}>1$ then risk exists and needs to be controlled, whereas if $\mathrm{RQ} \leq 1$ then risk does not need to be controlled but all conditions need to be maintained so that the numerical value of RQ does not exceed 1 . 


\section{Health risk management}

Risk management or risk control will be carried out through several strategies, as follows:

Reducing the concentration of pollutants

Reducing the rate of consumption

$$
C=\frac{R f D \times W b \times t_{\text {avg }}}{R \times F_{e} \times D_{t}}
$$

Reducing contact time

$$
R=\frac{R f D \times W_{b} \times t_{a v g}}{C \times f_{e} \times D_{t}}
$$

$$
D t=\frac{R f D \times W_{b} \times t_{a v g}}{C \times R \times F_{e}}
$$

\section{RESULT}

\section{Concentration Cd and Cr metals}

From the results of the laboratory analysis it was found that the concentrations of cadmium and chromium at 18 location points are as follows:

Table-1: Concentrations of Cadmium (Cd) and Chromium (Cr) Metals in Seawater, Sediments and Shellfish in the Jeneponto Coastal Area in 2017

\begin{tabular}{|c|c|c|c|c|c|c|c|c|}
\hline \multirow{2}{*}{ Sample Code } & \multicolumn{2}{|c|}{ Sea water $(\mathbf{m g} / \mathbf{L})$} & \multicolumn{2}{l|}{ Sediment $\mathbf{( m g / K g})$} & \multicolumn{2}{l|}{ Shellfish $\mathbf{( m g / K g})$} & \multicolumn{2}{c|}{ BCF Value } \\
\cline { 2 - 9 } & $\mathbf{C d}$ & $\mathbf{C r}$ & $\mathbf{C d}$ & $\mathbf{C r}$ & $\mathbf{C d}$ & $\mathbf{C r}$ & $\mathbf{C d}$ & $\mathbf{C r}$ \\
\hline Point 1 & 0.067 & 0.352 & 0.011 & 18.180 & 0.953 & 6.070 & 14.22 & 17.24 \\
\hline Point 2 & 0.060 & 0.386 & 1.278 & 23.990 & 0.813 & 5.340 & 13.55 & 13.83 \\
\hline Point 3 & 0.047 & 0.364 & 2.240 & 17.830 & 1.258 & 6.400 & 27.76 & 17.58 \\
\hline Point 4 & 0.018 & 0.398 & .988 & 17.780 & 0.866 & 7.510 & 48.11 & 18.86 \\
\hline Point 5 & 0.010 & 0.409 & 1.210 & 16.610 & 0.436 & 5.810 & 43.6 & 14.20 \\
\hline Point 6 & 0.015 & 0.386 & 0.064 & 21.950 & 0.230 & 1.220 & 15.33 & 3.16 \\
\hline Point 7 & 0.008 & 0.398 & 0.664 & 23.760 & 0.541 & 9.430 & 67.62 & 23.69 \\
\hline Point 8 & 0.024 & 0.455 & 0.703 & 17.670 & 0.143 & 1.890 & 5.95 & 4.15 \\
\hline Point 9 & 0.029 & 0.432 & 1.493 & 21.640 & 0.142 & 1.990 & 4.89 & 4.60 \\
\hline Point 10 & 0.033 & 0.420 & 1.157 & 21.940 & 0.114 & 1.940 & 3.45 & 4.62 \\
\hline Point 11 & 0.119 & 0.318 & 3.800 & 3.020 & 1.560 & 1.560 & 13.10 & 4.90 \\
\hline Point 12 & 0.114 & 0.273 & 3.280 & 1.990 & 1.910 & 1.425 & 16.75 & 5.21 \\
\hline Point 13 & 0.077 & 0.318 & 3.470 & 1.640 & 2.010 & 0.194 & 26.10 & 0.61 \\
\hline Point 14 & 0.022 & 0.394 & 4.450 & 1.440 & 2.900 & 0.202 & 131.8 & 0.51 \\
\hline Point 15 & 0.042 & 0.455 & 4.170 & 1.140 & 2.570 & 0.240 & 61.19 & 0.52 \\
\hline Point 16 & 0.043 & 0.045 & 3.460 & 1.560 & 2.580 & 0.208 & 60.00 & 4.62 \\
\hline Point 17 & 0.060 & 0.500 & 2.880 & 2.420 & 1.670 & 0.354 & 27.83 & 0.71 \\
\hline Point 18 & 0.076 & 0,424 & 1.660 & 2.840 & 1.550 & 0.372 & 20.39 & 0.87 \\
\hline Mean & 0.048 & 0.374 & 2.054 & 12.0788 & 1.236 & 2.861 & 37,96 & 7.78 \\
\hline Minimum & 0.008 & 0.045 & 0.011 & 1.140 & 0.114 & 0.194 & 3.45 & 0.51 \\
\hline Maximum & 0,119 & 0.500 & 4.450 & 23.990 & 2.900 & 9.430 & 131.8 & 23.69 \\
\hline Standard Deviation & 0,033 & 0.098 & 1.437 & 9.499 & .907 & 3.011 & & \\
\hline Quality standards & $0.001 * * *$ & $0.005 * * *$ & $0.99 * * * *$ & $43 * * * *$ & $* 1.0$ & $2.0 * *$ & & \\
\hline
\end{tabular}

Note: * Indonesia Regulation of the Head of National Agency of Drug and Food Control Number 23 Year 2017 Concerning Maximum Limits of Heavy Metal Contamination in Processed Food, ** National Standard of China on Maximum Levels of Contaminants In Foods 2006, *** Indonesia Minister of Environment Regulation No 51 of 2004 concerning Sea Water Quality Standards, **** Consensus-Based Sediment Quality Guidelines 2003

The results of examination of samples in the laboratory showed that from 18 sampling points the average concentration of Cd was $0.048 \mathrm{mg} / 1$, and $\mathrm{Cr}$ was $0.374 \mathrm{mg} / 1$. In sediments the concentrations of Cd were $2,054 \mathrm{mg} / \mathrm{kg}$ and $\mathrm{Cr} 12,08888 \mathrm{mgkg}$. Padangang found Cd concentrations of 1,236 mg / kg and Cr 2,861 mg / kg. The average value of BCF cadmium 37.96 means that the accumulative is low and the average value of BCF chromium is 7.78 which means the accumulative is low (BCF <100). $\mathrm{Cd}$ and $\mathrm{Cr}$ in shellfish must still be wary of because of the accumulative nature of heavy metals themselves if consumed continuously for long periods of time causing chronic poisoning (Agency for Toxic 
Substances and Disease Registry (ATSDR), 2012; Basha, Murthy and Jha , 2008; Xia et al., 2019). The effects that can be caused by consumption of heavy metals ( $\mathrm{Cd}$ and $\mathrm{Cr}$ ) can cause damage to the physiological system of the body such as the kidneys, liver, lungs, central nervous system, heart, blood circulation system, gastrointestinal, anemia, reproductive system damage and cancer (Agency for Toxic Substances and Disease Registry (ATSDR), 2012).

\section{Exposure Analysis and Risk Characterization}

Table-2: Intake and Risk Level of Consumption of Shellfish Containing Cadmium and Chromium in Communities in the Jeneponto Coastal Area in 2017

\begin{tabular}{|c|c|c|c|}
\hline Gender & Chemical Species & Intake (mg/kg/day) & Level of risk (RQ) \\
\hline \multirow{2}{*}{ Male } & $\mathrm{Cd}$ & 5.62 & 11.24 \\
\cline { 2 - 4 } & $\mathrm{Cr}$ & 13.02 & 4.34 \\
\hline \multirow{2}{*}{ Female } & $\mathrm{Cd}$ & 7.8 & 15.60 \\
\cline { 2 - 4 } & $\mathrm{Cr}$ & 18.24 & 6.08 \\
\hline
\end{tabular}

From table 3 it is known that both men and women RQ> 1 means that people in the Jeneponto coastal area have a non-carcinogenic risk from the consumption of shells containing cadmium and chromium. Non-carcinogenic effects that can be caused by $\mathrm{Cd}$ and $\mathrm{Cr}$ exposure include damage to the digestive tract, nervous system, genotoxic, kidney, liver, circulatory system and heart, reproduction, and growth disorders (Agency for Toxic Substances and Disease Registry (ATSDR)), 2012). In addition to knowing the level of risk of $\mathrm{Cd}$ and $\mathrm{Cr}$ exposure resulting from the consumption of shellfish obtained from the Jeneponto coastal area, this study also provides calculations related to risk management that can be used as recommendations to reduce health risks that can be caused by heavy metals $\mathrm{Cd}$ and $\mathrm{Cr}$ in the future . Possible risk management by the community is to reduce the rate of intake and frequency of consumption of shellfish taken from the Jeneponto coastal area. Recommended figures can be seen in table 4.

Table-3: Risk Management of Cadmium and Chromium Exposure to Communities in the Jeneponto Coastal Region in 2017

\begin{tabular}{|c|c|c|c|c|c|c|c|c|}
\hline \multirow{3}{*}{ Responden } & \multicolumn{9}{|c|}{ Risk Management } \\
\cline { 2 - 9 } & \multicolumn{2}{|c|}{$\begin{array}{c}\text { Concentration } \\
\text { (mg/Kg) }\end{array}$} & \multicolumn{2}{c|}{$\begin{array}{c}\text { Rate of intake } \\
\text { (g/day) }\end{array}$} & \multicolumn{2}{c|}{$\begin{array}{c}\text { Frequency } \\
\text { (day/year) }\end{array}$} & $\begin{array}{c}\text { Duration of Exposure } \\
\text { (year) }\end{array}$ \\
\cline { 2 - 9 } & $\mathrm{Cd}$ & $\mathrm{Cr}$ & $\mathrm{Cd}$ & $\mathrm{Cr}$ & $\mathrm{Cd}$ & $\mathrm{Cr}$ & $\mathrm{Cd}$ & $\mathrm{Cr}$ \\
\hline Male & 0.10 & 0,65 & 0.17 & 0,46 & 8.5 & 22.10 & 1.77 & 4.6 \\
\hline Female & 0.07 & 0,47 & 0.12 & 0.32 & 6.09 & 15.78 & 1.26 & 3.2 \\
\hline
\end{tabular}

The rate of $\mathrm{Cd}$ intake allowed for men should not exceed $0.17 \mathrm{~g} /$ day and women $0.12 \mathrm{~g} / \mathrm{day}$. While the rate of $\mathrm{Cr}$ intake for men should not exceed $0.46 \mathrm{~g} /$ day and women $0.32 \mathrm{~g} / \mathrm{day}$. For the frequency of consumption must also be limited to $\mathrm{Cd}$ exposure in men may not exceed 8 days / year and women may not exceed 6 days / year. As for $\mathrm{Cr}$ exposure to shellfish consumption is limited to 22 days / year for men and women 15 days / year. For men in heavy metal $\mathrm{Cd}$ exposure, the average appearance of the disease is 1.7 years and for women 1.2 years. For men in $\mathrm{Cr}$ heavy metal exposure averaged 4.6 years and 3.2 years for women.

\section{DISCUSSION}

Based on the results of examination of green mussels (Perna viridis) on the coast of Mallasoro Village and Bonto Ujung Village, the highest content of Cd was obtained at point $16,2.580 \mathrm{mg} / \mathrm{kg}$, $\mathrm{Cr}$ at point 7, concentration of $9,430 \mathrm{mg} / \mathrm{kg}$. This is in accordance with the characteristics of the Jeneponto coast which causes many green shells and blood shells in the area. The use of coal as fuel in PLTU activities can produce heavy metals. In addition, motorboat activity also affects the levels of heavy metals in the water. The content of heavy metals in green shells is also influenced by water conditions. The level of bioaccumulation is influenced by many factors, such as temperature rise, $\mathrm{pH}$ decrease and water salinity. The difference between shells and other organisms is the type of shell that is able to accumulate metals more than other aquatic biota because of its permanent nature, slow to be able to avoid exposure to pollution and have a high tolerance for heavy metal concentrations [3].

From data on heavy metal concentrations $(\mathrm{Cd}$ and $\mathrm{Cr}$ ) it is known that the average concentration of $\mathrm{Cd}$ and $\mathrm{Cr}$ in seawater is $0.048 \mathrm{mg} / \mathrm{L}$ and $0.374 \mathrm{mg} / \mathrm{L}$. Cd concentration range values are $0.0008-0.119 \mathrm{mg} / \mathrm{L} \mathrm{and} \mathrm{Cr}$ concentrations range from 0.045 to $0.500 \mathrm{mg} / \mathrm{L}$. Based on Indonesia Minister of Environment Regulation Number 51 of 2004 concerning Sea Water Quality Standards, the heavy metal content of Cd in the seawater of the Jeneponto coastal area has exceeded the allowable threshold value of $0.001 \mathrm{mg} / \mathrm{L}$ and the heavy metal content of $\mathrm{Cr}$ in the seawater of the Jeneponto coastal area has exceeded the permitted threshold value of $0.005 \mathrm{mg} / \mathrm{L}$. 
The average concentrations of $\mathrm{Cd}$ and $\mathrm{Cr}$ in sediments were $2,054 \mathrm{mg} / \mathrm{kg}$ and $12.0788 \mathrm{mg} / \mathrm{kg}$. The average concentration was found to have exceeded the quality standards recommended by the Consensus-Based Sediment Quality Guidelines in 2003. The average concentration of $\mathrm{Cd}$ in shellfish was $1,236 \mathrm{mg} / \mathrm{kg}$. If related to cadmium $(\mathrm{Cd}) \mathrm{heavy}$ metal content recommended by Indonesia Regulation of the Head of National Agency of Drug and Food Control Regulation number 23 of 2017 concerning the maximum limit of heavy metal contamination in processed food that is the maximum limit of cadmium heavy metal (Cd) for bivalve quality standards for processed mollusks is $1.0 \mathrm{mg} / \mathrm{kg}$, it can be stated that the content of cadmium $(\mathrm{Cd})$ heavy metals that accumulates in shellfish exceeds the set limits, meaning that shellfish are not suitable for consumption by the public. The average concentration of $\mathrm{Cr}$ in shellfish was $2,861 \mathrm{mg} / \mathrm{kg}$. The concentration of chromium (Cr) in these shells based on the National standards of China on Maximum Levels of Contaminants in Foods is known that it has passed the recommended quality standard of $2.0 \mathrm{mg} / \mathrm{kg}$. This proves that shellfish taken from the Jeneponto coast are no longer suitable for public consumption.

\section{CONCLUSION}

The concentration of $\mathrm{Cd}$ and $\mathrm{Cr}$ in seawater on the Jeneponto coast has exceeded the quality standard stipulated by Indonesia Minister of Environment Regulation No.51 of 2004. Whereas the concentration of Cd and Crin sediments has exceeded the quality standard set by the 2003 Consensus-Based Sediment Quality Guidelines. and Cr in clams taken from the Jeneponto coast is no longer suitable for consumption. Based on the RQ calculation results, it is found that the Jeneponto coastal community has an RQ $>1$ which means that the community has a non-carcinogenic risk from the consumption of shellfish obtained from the Jeneponto coast. Therefore, it is necessary to do risk management by reducing or limiting the consumption of shellfish.

It is expected that the local government, especially the health department and the environmental department, will conduct monitoring in the coastal area of Jeneponto Regency; It is expected that the Bosowa Steam Power Plant operating in Jeneponto Regency will process existing waste before it is discharged into water bodies, so that it does not pollute the surrounding environment, especially the coastal areas; For the public to pay more attention to the food that they want to process, in order to avoid the effects that are harmful to health.

\section{REFERENCES}

1. Basha, S., Murthy, Z. V. P., \& Jha, B. (2008). Biosorption of hexavalent chromium by chemically modified seaweed, Cystoseira indica. Chemical Engineering Journal, 137(3), 480-488.

2. Wang, C., Zhang, Y., Shi, Y., Liu, H., Zou, C., Wu, H., \& Kang, X. (2017). Research on collaborative control of Hg, $\mathrm{As}, \mathrm{Pb}$ and $\mathrm{Cr}$ by electrostatic-fabric-integrated precipitator and wet flue gas desulphurization in coal-fired power plants. Fuel, 210, 527-534.

3. Darmono. (1995). Logam dalam sistem biologi makhluk hidup. Penerbit Universitas Indonesia.

4. Mahasri, G., Eshmat, M. E., \& Rahardja, B. S. (2014). Analisis Kandungan Logam Berat Timbal (Pb) dan Cadmium (Cd) pada Kerang Hijau (Perna viridis L.) di Perairan Ngemboh Kabupaten Gresik Jawa Timur [Analysis Of Heavy Metal Content Of Lead (Pb) And Cadmium (Cd) Shells On Green (Perna viridis L.) On Water District Ngemboh Gresik East Java]. Jurnal Ilmiah Perikanan dan Kelautan, 6(1), 101-108.

5. Da Silva, W. R., da Silva, F. B. V., Araújo, P. R. M., \& do Nascimento, C. W. A. (2017). Assessing human health risks and strategies for phytoremediation in soils contaminated with $\mathrm{As}, \mathrm{Cd}, \mathrm{Pb}$, and $\mathrm{Zn}$ by slag disposal. Ecotoxicology and environmental safety, 144, 522-530.

6. LaGrega, M. D., Buckingham, P. L., \& Evans, J. C. (2001). Hazardous waste management. 2nd edn. Boston: McGraw-Hill.

7. El Nemr, A., Khaled, A., Moneer, A. A., \& El Sikaily, A. (2012). Risk probability due to heavy metals in bivalve from Egyptian Mediterranean coast. The Egyptian Journal of Aquatic Research, 38(2), 67-75.

8. National Research Council. Committee on Biologic Effects of Atmospheric Pollutants. (1974). Vanadium. National Academy of Sciences.

9. Papp, J. F. (2009). Commodity Summary 2009: Chromium. United States Geological Survey. Retrieved, 03-17.

10. Velusamy, A., Kumar, P. S., Ram, A., \& Chinnadurai, S. (2014). Bioaccumulation of heavy metals in commercially important marine fishes from Mumbai Harbor, India. Marine pollution bulletin, 81(1), 218-224.

11. Speight, J. G. (2017). 'Introduction Into the Environment', in Environmental Inorganic Chemistry For Engineers. Elsevier Inc, 283-331.

12. Jusuf, R., Sastiono, A., \& Widowati, W. (2008). Efek Toksik Logam Pencegahan dan Penanggulangan Pencemaran. 